Special issue

EDUCATIONAL PSYCHOLOGY

FROM A CONTEMPORARY PERSPECTIVE

\title{
Educational Psychology in Europe
}

\author{
Elinor Schad ${ }^{\mathrm{a}}$, Christopher Arnold ${ }^{\mathrm{b}}$ \\ ${ }^{a}$ Department of Psychology, Lund University, Sweden \\ ${ }^{b}$ Tavistock and Portman NHS Trust, London, UK
}

Today, Russia is a member of the European Federation of Psychological Associations (EFPA) and in the summer 2019 the Russian Psychological Society was the host to the 16th European Congress of Psychology (ECP) in Moscow, gathering psychologists from all over the world. In connection with the $2019 \mathrm{ECP}$, this special edition has been compiled by members of EFPA's Standing Committee on Psychology in Education (SCPiE) and represents a collection of papers highlighting the range of work that educational psychologists undertake with schools and youth. This volume is also the next step for the EFPA Standing Committee for Psychologists in Education to strengthen and promote educational psychology in Europe, in order to reach our end goal: efficient and wellfunctioning institutions of learning.
Key words:

educational psychology, European Federation of Psychological Associations (EfPA), 16th European Congress of Psychology (ECP), EFPA's

Standing Committee on Psychology in Education (SCPiE)

\section{Introduction}

To be invited to edit a Russian journal's special edition devoted to psychology in schools is indeed a great honour, and we are grateful for this opportunity to showcase state of the art of educational psychology in different European locations in this publication.

The study of human learning has been at the center of psychological research for over a century, and Russian psychologists have earned envied reputations in this field. Names such as Pavlov, Vygotsky, and Luria are known across the whole world and stand alongside other giants in this field such as Piaget, Binet, Kohler, Milgram, and Bandura. 
Educational psychology also has a long and proud history stretching over 100 years, stemming from the fact that around the turn of the last century it became compulsory for most children in the industrialized world to attend school. The view of education and children's prerequisites for learning changed dramatically during this period, as people realized that society had a great responsibility for children's education and development, and that therefore children should not be exploited as cheap labour, but viewed as an investment for the future of society. During this time, questions also arose about children's prerequisites for learning. Alfred Binet, for example, not only designed the first aptitude test, but also had an immense interest in cognitive development, group conformity, individual differences, etc. (Siegler, 1992). In Sweden, as in many other countries, psychologists were involved in school placement and aptitude testing. The first person to have a job described as an applied psychologist in the UK was an educational psychologist (Arnold and Hardy, 2013). Much has happened since then, and today we face other challenges and problems on the local, national and international arena.

Today, Russia is a member of the European Federation of Psychological Associations (EFPA) and in the summer 2019 the Russian Psychological Society was the host to the 16th European Congress of Psychology (ECP) in Moscow, gathering psychologists from all over the world. This special edition has been compiled by members of EFPA's Standing Committee of Psychologists in Education (SCPiE) and represents a collection of papers highlighting the range of work that psychologists undertake with schools and young people. This volume is also the next step for the EFPA Standing Committee for Psychologists in Education to strengthen and promote educational psychology in Europe. Previous work includes for example, the publication Inclusive Education Practice in Europe (Arnold \& Horan, 2017) published by University College London Press in 2017.

Themes in this issue are also themes, which unite us. The importance of schools in the promotion of positive mental health in young people, the focus on vulnerable young people, and the recognition of the different educational needs of different groups are indeed pan-national.

What is unique about this edition is the nature of the contributors. They are all hands-on practitioners applying psychology in different areas, yet able to communicate their findings and applications comprehensively, to promote positive outcomes for different groups.

\section{Articles in this Issue}

This special issue of Psychology in Russia: State of the Art focuses on contemporary educational psychology from a European perspective. Topics covered display the broadness of the field and reflect educational psychology from both a researcher's and a practitioner's perspective.

In the first article, Schwarz and Gawrilow (2019) describe an intervention study in which they examined the potential benefits a program called WOOP, on improving self-regulation among school children on a day-to-day basis. Although larger studies are needed, the authors show that self-regulatory interventions can help children formulate and reach their goals, and in the process improve their self-assessed self-regulation. 
Work-related health and working conditions among teachers in Sweden are described by Schad and Johnsson (2019). With a comprehensive cross-sectional survey, the authors report on teachers' problems with recovery from work, insufficient separation between work and spare time, sleeping difficulties, and symptoms of depression. The results are indicative of the difficulties society faces when one of the largest groups of employees fares ill.

The experience and behaviour of children as well as their emotional development are highly dependent on how they perceive their support by their teachers. In a large cross-sectional survey, Lazarova, Hlado, and Hlouskova (2019) explore how last year, students at public vocational schools in the Czech Republic perceived the support of their teachers. Not indicating any gender differences, the results show that the students overall feel supported. The authors also show perception of teacher support to be predicted by study results, field of study, as well as satisfaction with study results. The results of this work, indicating a correlation between teacher support and career adaptability, could also have bearing on future life satisfaction among pupils.

Hatzichristou, Lianos, and Lampropoulou (2019) delineate the importance of new delivery models of school psychological services, putting evidence-based prevention and intervention programs for supporting school communities at center stage. The authors elegantly link theory, training, and research on delivery models, with interventions in the Greek educational system. They place a special emphasis on the responsibility universities have for the provision of preventive health services for youths.

A comparative study examining the state of evidence-based practice among school psychologists in three European countries is offered by Juriševič, Lazarová, and Gajdošová (2019). The authors discuss obstacles preventing the advancement of school psychology, from educational quality to employment conditions, highlighting the importance of more cross-cultural research.

Juriševič and Žerak (2019) examine the attitudes of students, parents, and teachers towards gifted children's need for education adjusted to their specific needs. Combining qualitative and quantitative methods, they authors point to the importance of comprehensive approaches to education for this group of students often misunderstood and underrepresented.

Bahia and Nogueira (2019) report on a large-scale initiative by the Southern Regional Delegation of the Order of Portuguese Psychologists, in which they reach out to the public with an exhibition showcasing "emotions and emotional regulation". More than 9,000 persons took part in this interactive and mobile exhibition. Based on theories of learning and development, the authors discuss the psychoeducational importance of such opportunities for citizens and society.

In this day and age, with the Internet and social media always in close proximity, the approach of Mironova (2019) is especially interesting. In her study with Russian secondary school children, she delves into the psycho-didactic foundations of developing teenagers' creative interaction with lyric poetry. Compared to a control group, the participants in the intervention group showed increased creative interaction with the reading and workbook material, showing that interacting with poetry can be a valuable experience for todays' teenagers. 
In their article on reading performance in adults with intellectual and developmental disability, León and León-López (2019) point to the importance of giving students enough time-on-task for the fulfillment of their potential. In this large study, they found that a population of 450 adults with Intellectual and Developmental Disability, compared with a population of university students $(\mathrm{N}=200)$, were found to achieve higher than expected results, sometimes surpassing the comparison group, if they were given enough time to complete the tasks.

Children with haemophilia face both prejudice and overprotection, as teachers often hesitate to involve them in sports at school. In their study, Dinet, Bauchet, and Hoareau (2019) explore ways to influence the mental representations of children with haemophilia, their parents, and their teachers, utilizing a participatory game design process for an innovative digital tool. This might in the long run improve help self-esteem, learning, and inclusion in schools among children with haemophilia.

Henriksson, Küller Lindén, and Schad (2019) assessed the well-being and stress of a population of senior high school students and found their reporting of these factors to be strongly linked with their reporting of their learning situation, their relation to family and friends, and their possibility to recuperate after school. Henriksson and her co-authors' results point to the importance of teachers' interactions with pupils, building trusting relationships, and a supportive school environment.

Petrulyte and Guogienè (2019) in their article aim to investigate social-emotional health and self-esteem of adolescents in a large Lithuanian sample, by comparing adolescent social-emotional health and self-esteem among 12-15 year olds and 16-19 year olds, as well as exploring possible gender differences. School psychologists in Lithuania will be able to use this survey to monitor adolescent psychological health. The work therefore constitutes an important step in the development of school psychological services in Lithuania.

In their article, Bunn, Turner, and Macro (2019) describe an evaluation of a commercially available toolkit aimed at supporting pupils' social, emotional, and mental health. Using a mixed methodology, they assess the functionality of the training material as used by a team comprised of educational psychologists, clinical psychologists, and specialist teachers. Their findings suggest evidence of improved skills and knowledge in the pupils' social, emotional, and mental health.

\section{Conclusion}

In this day and age, knowing how students and teachers fare in school is vitally important to ensure our future. Only by understanding the challenges that our students and teachers face can we start to promote and develop our educational practices for the benefit of future generations.

We are proud to present this body of work and we hope that you find our colleagues' contributions inspirational. 


\section{References}

Arnold, C., \& Hardy, J. (Eds.). (2013). British educational psychology: The first hundred years (2nd edition). Leicester: BPS.

Arnold, C., \& Horan, J. (Eds.). (2017). Inclusive educational practice in Europe: Psychological perspectives. London: UCL Press.

Bahia, S., Nogueira, J. (2019). The Importance of Communicating Psychological Concepts in Educational Contexts: a Portuguese Exhibition. Psychology in Russia: State of the Art, 12(4), 118-134. https://doi.org/10.11621/pir.2019.0407

Bunn, H., Turner, G., Macro, E. (2019). The Wellbeing Toolkit Training Programme: A Useful Resource for Educational Psychology Services? Psychology in Russia: State of the Art, 12(4), 210225. https://doi.org/10.11621/pir.2019.0413

Dinet, J., Bauchet, C., Hoareau, L. (2019). Collaborative Game Design with Children with Hemophilia as a Tool for Influencing Opinions about Physical Activity at School. Psychology in Russia: State of the Art, 12(4), 159-171. https://doi.org/10.11621/pir.2019.0410

Hatzichristou, C., Lianos, P., Lampropoulou, A. (2019). Supporting Vulnerable Groups of Students in Educational Settings: University Initiatives and Partnerships. Psychology in Russia: State of the Art, 12(4), 65-78. https://doi.org/10.11621/pir.2019.0404

Henriksson, f., Küller Lindén, E.., Schad, E. (2019). Well-being and Stress Among Upper Secondary School Pupils in Sweden. Psychology in Russia: State of the Art, 12(4), 172-195. https://doi. org/10.11621/pir.2019.0411

Juriševič, M., Lazarová, B., Gajdošová, E. (2019). Evidence-Based Practice for Psychologists in Education: A Comparative Study from the Czech Republic, Slovakia, and Slovenia. Psychology in Russia: State of the Art, 12(4), 79-100. https://doi.org/10.11621/pir.2019.0405

Juriševič, M., Žerak, U. (2019). Attitudes towards Gifted Students and Their Education in the Slovenian Context. Psychology in Russia: State of the Art, 12(4), 101-117. https://doi.org/10.11621/ pir.2019.0406

Lazarová, B., Hlado, P., Hloušková, L. (2019). Perception of Teacher Support by Students in Vocational Education and Its Associations with Career Adaptability and Other Variables. Psychology in Russia: State of the Art, 12(4), 47-64. https://doi.org/10.11621/ pir.2019.0403

Leon, J.A., León-López, A. (2019). Reading Performance in Adults with Intellectual and Developmental Disability (IDD) When They Read Different Kinds of Texts. Psychology in Russia: State of the Art, 12(4), 148-158. https://doi.org/10.11621/pir.2019.0409

Mironova, K. (2019). The Principle of Open Individuality as a Basis for Teenagers' Creative Interaction with Lyric Poems. Psychology in Russia: State of the Art, 12(4), 130-142. https://doi.org/10.11621/ pir.2019.0408

Petrulytè, A., Guogienė, V., Rimienė, V. (2019). Adolescent Social Emo- tional Health, Empathy, and Self-esteem: Preliminary Validation of the Lithuanian Version of the SEHS-S Questionnaire. Psychology in Russia: State of the Art, 12(4), 196-209. https://doi.org/10.11621/pir.2019.0412

Schad, E., Johnsson, P. (2019). Well-Being and Working Conditions of Teachers in Sweden. Psychology in Russia: State of the Art, 12(4), 23-46. https://doi.org/10.11621/ pir.2019.0402

Schwarz, U., Gawrilow, C. (2019). Measuring and Compensating for Deficits of Self-Regulation in School Children via Ambulatory Assessment. Psychology in Russia: State of the Art, 12(4), 8-22. https://doi.org/10.11621/pir.2019.0401

Siegler, R.S. (1992). The other Alfred Binet. Developmental Dsychology, 28(2), 179. https://doi. org/10.1037/0012-1649.28.2.179

To cite this article: Schad, E., Arnold, C. (2019). Educational Psychology in Europe. Psychology in Russia: State of the Art, 12(4), 2-18. DOI: 10.11621/pir.2019.0400 